IIIIIIIIIIIIIIIIIIIIIIIIIIII

$$
\text { ミニレビュー }
$$

|IIIIIIIIIIIIIIIIIIIIIIIIIIII

\title{
医農薬開発におけるフッ素官能基の導入方法”
}

\author{
河 田 恒 佐* \\ 東ソー・エフテック株式会社
}

（2015年11月 20 日受理）

\section{Introduction method of the fluorine functional group for development of Pharmaceuticals and Agrochemicals}

\author{
Kosuke KawadA \\ TOSOH F-TECH, INC., 4988 Kaisei-cho, Shunan, Yamaguchi 746-0006, Japan
}

Keywords: fluorination, trifluoromethylation, perfluoroalkylation, buildingbrock, pharmaceutical, agrochemical.

\section{は じめに}

フッ素は, 他のハロゲン元素と比べて極めて大きな電気陰 性度と大きな炭素-フッ素結合エネルギーを有し，かつ水素 に次いで小さな van der Waals半径を有する元素である（表 1) ${ }^{1)}$.

このようなフッ素原子を大量に含む有機化合物（パーフル オロ化合物）は耐熱性や耐薬品性，耐候性に優れており，こ れらの特徴を活かしてさまざまな工業材料の分野での応用 展開が進められている. 一方, 医薬・農薬の分野では少量 の（1～3 個）フッ素原子を分子の特定の位置に導入するこ とで, 劇的にその生理活性が向上する場合が数多く見られ る. 必ずしもす心゙ての医薬・農薬についてその生理活性発現 機構が明らかになっているわけではないが, これら化合物の 多くはフッ素原子の小ささに起因するミミック効果や脂溶性 の向上などを利用した生体内への取り込み効果や, 水素原子 をフッ素原子に置換したことによる代謝抑制効果に起因する

\footnotetext{
\#第40回大会シンポジウムを取りまとめた解説.

* T 746-0006 山口県周南市開成町 4988

E-mail: kosuke-kawada@f-techinc.co.jp

(c) 日本農薬学会
}

ものと考えられており，最近ではこれら医・農薬分野におい て活発に含フッ素化合物の開発研究が進められている.

含フッ素化合物の合成方法としては, 比較的低分子の含 フッ素化合物を出発原料として使用し，有機合成手法を駆使 して目的とする化合物の構造を組み立てていくビルディング ブロック法と, 塩素, 臭素, ヨウ素等のハロゲン原子や, 水 酸基，カルボニル基等の官能基を足がかりにして，直接フッ 素原子やパーフルオロアルキル基を導入するフッ素化法があ る.

本稿では，フッ素原子やパーフルオロアルキル基の導入方 法について概説するとともに, 実際の医薬・農薬類への展開 例についていくつか紹介する.

\section{1. フッ素原子導入法}

フッ素原子の導入方法は, 大別して, フッ素原子を $\mathrm{F} マ イ$ ナスとして利用する求核的フッ素化方法と, Fプラスとして 利用する親電子的フッ素化方法およびFラジカルとしてフッ 素化する方法に分類できる. 特に最近では, 求核的フッ素化 方法に使用するためのフッ素化剂や, 親電子的フッ素化方法 に使用するフッ素化剂が数多く開発され, 試薬としても入手 できるようになってきている。 
表 1. フッ素元素の特性

\begin{tabular}{lcccccc}
\hline & 水素 & 酸素 & フッ素 & 塩素 & 臭素 & ヨウ素 \\
\hline 原子半径 $(\mathrm{pm})$ & 53 & 74 & 64 & 99 & 114 & 135 \\
van der Waals半径 $(\mathrm{pm})$ & 120 & 145 & 135 & 186 & 195 & 215 \\
電気陰性度 & 2.1 & 3.5 & 4.0 & 3.0 & 2.8 & 1142 \\
イオン化エネルギー $(\mathrm{kJ} / \mathrm{mol})$ & 1312 & 1313 & 1680 & 1255 & -324.5 & -295.1 \\
電子親和力 $(\mathrm{kJ} / \mathrm{mol})$ & -72.7 & -141.0 & -328.1 & -348.5 & 1007 \\
解離エネルギー $(\mathrm{kJ} / \mathrm{mol})$ & 436.0 & 498.4 & 158.8 & 242.6 & 192.8 & 151.1 \\
\hline
\end{tabular}

\section{1. 求核的フッ素化方法}

求核的フッ素化反応はその反応の制御が容易なことから, 古くから広く利用されてきている方法である.この目的に用 いるフッ素化剂はその構造および反応性からいくつかの群に 分類できる.

1）無機系フッ素化剂（図 1）

$\mathrm{HF}, \mathrm{HBF}_{4}, \mathrm{KF}$ は含フッ素化合物を工業的に製造するため に最も一般的に利用されているフッ素化剤である。 HFは二 重結合への付加反応や塩素化合物の置換反応（ハレックス反 応）に, $\mathrm{HBF}_{4}$ はバルツシーマン反応に, KFはハレックス反 応による $\mathrm{F}$ 原子の導入等に使用される. 一方, フッ素ガスと 臭素またはヨウ素との反応によって製造される $\mathrm{BrF}_{3}$ や $\mathrm{IF}_{5}$ な どのインターハロゲン類は非常に反応性の高い $\mathrm{F}^{-}$化剂とし て二重結合への付加反応や時には三級炭素上への直接フッ素 化反応等に利用できる (式1 $)^{2)}$. またこうして製造された比 較的低分子量の含フッ素化合物は, さらに複雑な含フッ素化 合物合成のための原料としても利用されている.

2) FAR型フッ素化剂（図2）

CTT（Yarovenko試薬）は比較的古くから知られている求 核型フッ素化剂である。このフッ素化剂はジエチルミンを CTFEに付加させることによって容易に合成することができ る. CTTは水酸基をフッ素に置換してモノフルオロ化合物 を合成する反応や，カルボニル基をジフルオロ化合物に誘導 する脱酸素型フッ素化反応に利用できる(式2 $)^{3 \mathrm{a})} . \mathrm{PPDA}^{3 \mathrm{~b}}$ (石川試薬）やTFEDMA ${ }^{3 \mathrm{c})}$ もこの分類に属する求核型フッ 素化剂であり，これら試薬も CTTと同様，ジアルキルアミ ンとパーフルオロオレフィンとの付加反応によって容易に合 成できる。これら FAR型フッ素化剂の特徵は, $\mathrm{S}_{\mathrm{N}} 2$ 型の置換 反応によってフッ素化が進行することにある．したがって光 学活性な水酸基を有する化合物をフッ素化する場合, 立体反 転した光学活性フッ素化合物を合成することができる.

3）DAST型フッ素化剂（図3）

DAST はジエチルアミノトリメチルシランと $\mathrm{SF}_{4}$ との反応 によって合成される ${ }^{4 a}$ ） ケトン，アルデヒドを容易にジフ ルオロ化できる（式 3$)^{4 \mathrm{~b})}$ ．FAR型フッ素化剂と比べて強力 なフッ素化剤であるが, その反面, 熱的には若干不安定で $85^{\circ} \mathrm{C}$ 近辺で爆発的に分解するとの報告もある. そのため反

$$
\begin{aligned}
& \text { 酸 }: \mathrm{HF}, \mathrm{HBF}_{4} \\
& \text { アルカリ金属 : } \mathrm{KF}, \mathrm{CsF}, \mathrm{NaF}, \mathrm{LiF}, \mathrm{AgF} \\
& \text { インターハロゲン: } \mathrm{BrF}_{3}, \mathrm{IF}_{5} \\
& \mathrm{CF}_{3}-\mathrm{CF}=\mathrm{CF}_{2} \underset{125^{\circ} \mathrm{C}, 7 \mathrm{hr}}{\stackrel{\mathrm{IF}_{5} / \mathrm{I}_{2}}{\longrightarrow}}\left(\mathrm{CF}_{3}\right)_{2} \mathrm{CF}-\mathrm{I}
\end{aligned}
$$

図1. 無機系フッ素化剂.

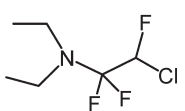

CTT

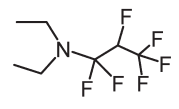

PPDA

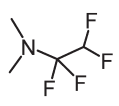

TFEDMA

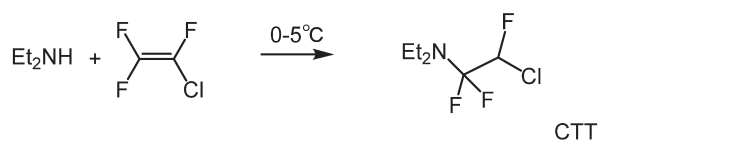

（式 2）

$$
\mathrm{C}_{6} \mathrm{H}_{5}\left(\mathrm{CH}_{2}\right)_{2} \mathrm{OH}+\mathrm{CTT} \underset{\mathrm{CHCl}_{3}}{\stackrel{\text { reflux 1-4h }}{\longrightarrow}} \mathrm{C}_{6} \mathrm{H}_{5}\left(\mathrm{CH}_{2}\right)_{2} \mathrm{~F}
$$

図2. FAR型フッ素化剂.

応条件の設定には注意を要する. DeoxoFluor ${ }^{4 c)}$ やMOST ${ }^{4 \mathrm{~d})}$ はDASTの熱的不安定性を改良するために開発された。アル キルアミノ基のアルキル側鎖に酸素原子を導入することに よって S原子上の反応性を若干落とすことによって安定性を 確保している.

一方, 最近報告されたXtalfluor ${ }^{4 \mathrm{e})}$ は, DAST 自体を $\mathrm{BF}_{3}$ で 処理することによって非常に安定な $\mathrm{BF}_{4}$ 塩として安定性の確 保と大量保存を容易にしたフッ素化剂である. 使用に際して は当量の HFを共存させることによってDAST様の反応性を 発現できる。

4）その他のフッ素化剂（図4）

$\mathrm{DFI}^{5 \mathrm{a}, \mathrm{b})}$ は 1,3-ジメチル-2-イミダゾリジノン（DMI）をホ スゲンで塩素化して得られる2-クロロイミダゾリニウムク ロリドをKFでフッ素化して合成する（式4）.

水酸基，ケトン，アルデヒドのフッ素化に使用できる. フッ素化後はDMIに戻るため原料としての再利用が可能と 


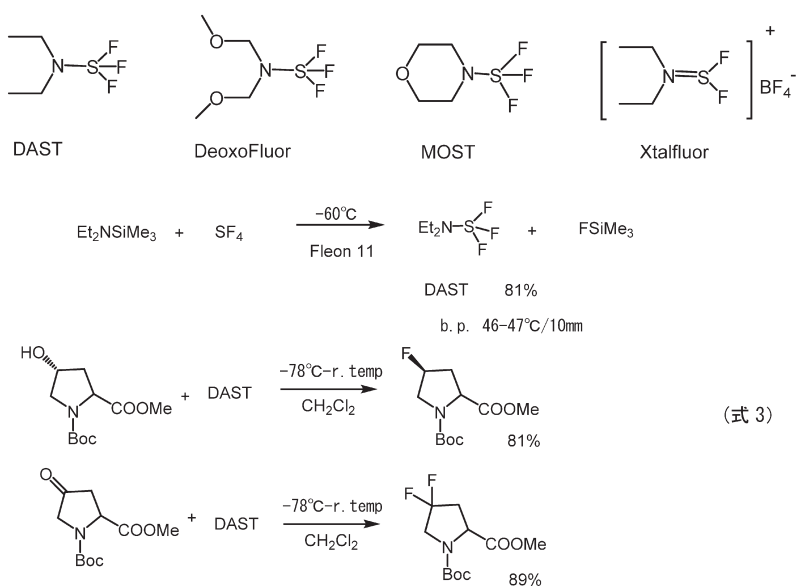

図3. DAST型フッ素化剂.

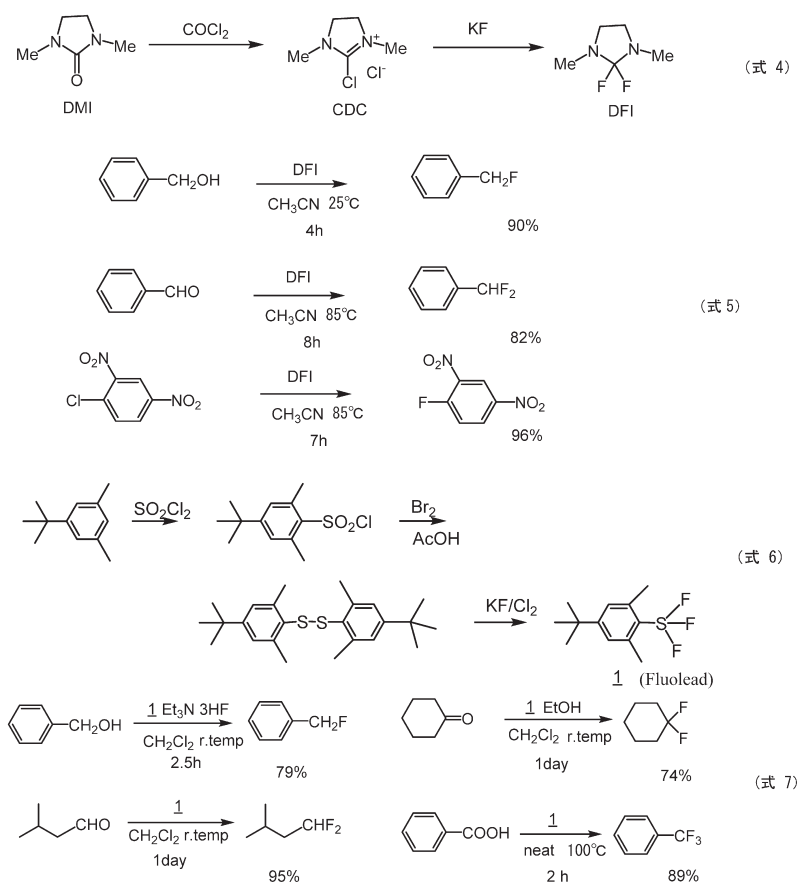

図4. その他のフッ素化剂.

なる（式5）.

Fluolead ${ }^{5, \mathrm{~d})}$ は最近開発された非常に安定な固体状の求核 型フッ素化剂である，対応するジスルフィド体をKF存在下 に, $\mathrm{Cl}_{2}$ で切断しながら KFでフッ素化して合成する（式6）. 水酸基, アルデヒド, ケトンに加えてカルボン酸もフッ素 化できる $\mathrm{SF}_{4}$ に匹敵する強いタイプのフッ素化剂である（式 7).

\section{2. 親電子的フッ素化方法}

親電子的フッ素化反応は, 電子豊富な基質に対して電子久 乏性のフッ素原子を活性種として導入する方法である。この 方法の基本はフッ素ガスによる反応であるが，その激しい反

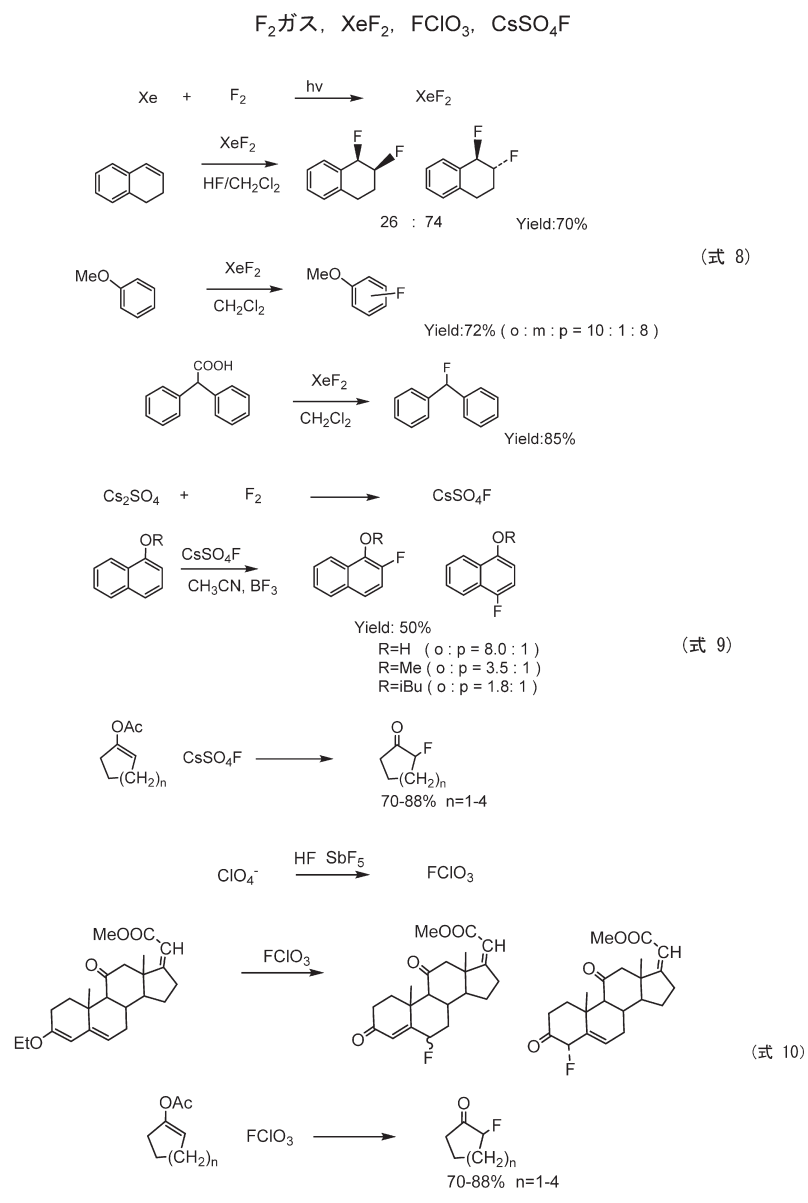

図5. 無機系フッ素化剂.

応性および毒性ゆえにフッ素ガスで選択的にフッ素原子を導 入するためには特別な装置と厳密な反応条件が必要になる. 一方, このフッ素ガス様の反応を安全かつ緩和な条件下で行 うことのできる親電子型フッ素化剂もいくつか開発されてい る.この親電子型フッ素化剂の大部分はフッ素ガスを用いて 合成される無機系または有機系化合物であり，これらもまた 構造およびその物性からいくつかの群に分類できる.

1）無機系フッ素化剂（図5）

$\mathrm{XeF}_{2}{ }^{6 \mathrm{a})}$ はフッ素ガスとキセノンを光照射下に直接反応さ せることによって合成できる融点が $129^{\circ} \mathrm{C}$ の昇華性固体で ある.この化合物はフッ素化剂として二重結合への付加反 応 ${ }^{6 b)}$ や芳香族化合物のフッ素化反応 ${ }^{6 c)}$, またカルボン酸と 反応させて脱炭酸フッ素化反応に使用できる $(\text { 式 } 8)^{6 \mathrm{~d})}$.

$\mathrm{CsSO}_{4} \mathrm{~F}$ は硫酸セシウムにフッ素ガスを反応させて合成す る. 芳香族化合物をフッ素化して対応するフルオロ化合物を 与えるほか ${ }^{6 \mathrm{e}}$, エノールアセテートと容易に反応してフル オロケトンを与える $\left(\right.$ 式9 ${ }^{6 \mathrm{ff}}$.

一方, $\mathrm{FClO}_{3}{ }^{6 \mathrm{~g})}$ はパークロレート $\left(\mathrm{ClO}_{4}^{-}\right)$を $\mathrm{HF} と \mathrm{SbF}_{5}$

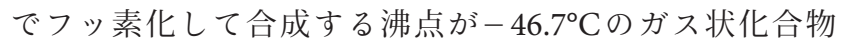
である，ステロイド類のフッ素化等に使用されている（式 
$10)$.

2）O-F結合を有するフッ素化剂（図6）

これらのフッ素化剂は, いずれもフッ素ガスを用いて合成 される. $\mathrm{CF}_{3} \mathrm{OF}^{7 \mathrm{a}-\mathrm{c})}$ は沸点が $-97^{\circ} \mathrm{C}$ の毒性のガス状化合物 であり, シリンダーで保管される.エノール $7 \mathrm{~d})$ や重結合 のフッ素化 ${ }^{7 \mathrm{f}}$, 芳香族のフッ素化 ${ }^{7 \mathrm{~g})}$ に利用できる(式11). 一方, $\mathrm{CF}_{3} \mathrm{COOF}, \mathrm{CH}_{3} \mathrm{COOF}$ は室温で不安定で容易に分解す るため, 対応するカルボン酸の $\mathrm{Na}$ 塩を, 溶媒中, 低温下に フッ素ガスで処理して合成し ${ }^{7 \mathrm{~h})}$, 直接基質と反応させるこ とによってフッ素化剂として使用する。これらのアセチルハ イポフルオリド類は芳香族 ${ }^{7 \mathrm{e})}$, エノール類をフッ素化する ことができるほか, 条件によっては二重結合への付加反応も 進行する $(\text { 式 } 12)^{7 \mathrm{i})}$.

3） N-F結合を有するフッ素化剛（図 7）

ここに示した N-F結合を有するフッ素化剂はすべてフッ 素ガスを用いて合成される安定な固体状化合物である ${ }^{8 \mathrm{a}-\mathrm{d})}$. いずれも試薬として市販されているほか，工業製品としての 大量使用も可能である. 有機溶剤に対する溶解度やフッ素化 剤としての反応性についてはそれぞれ一長一短があるが，い ずれも, 芳香族や活性メチレン, カルバニオン類に対して親 電子型フッ素化剂として有効に働く（式13）.

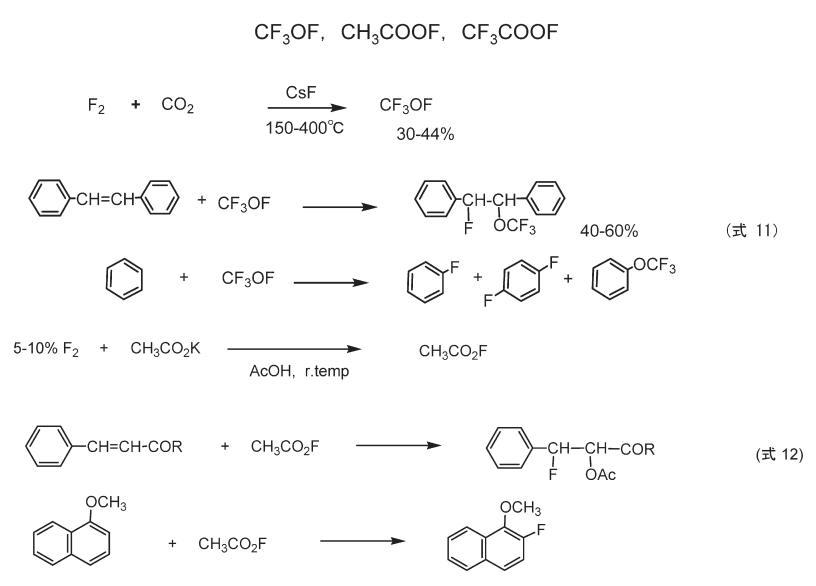

図6. O-F結合を有するフッ素化剂.

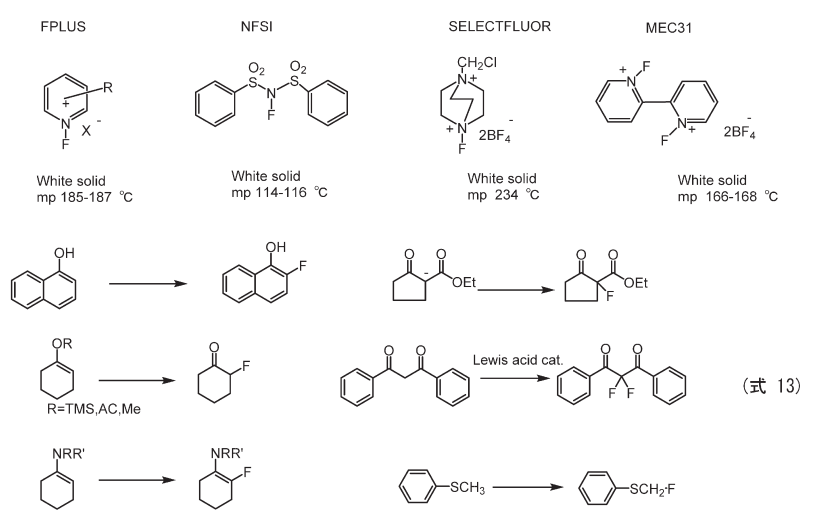

図7、N-F結合を有するフッ素化剤.

\section{2. フルオロアルキル基導入法}

フルオロアルキル基導入方法として最も幅広く検討されて いるのはトリフルオロメチル化反応である.このトリフルオ ロメチル化反応に使用されるトリフルオロメチル化剂には $\mathrm{CF}_{3}$ マイナスとして働く求核的 $\mathrm{CF}_{3}$ 化剂とその対岸に位置す る親電子的 $\mathrm{CF}_{3}$ 化剂および $\mathrm{CF}_{3}$ ラジカルとして働く $\mathrm{CF}_{3}$ 化剂 がある.そのほかにもジフルオロメチル基導入に使用するジ フルオロメチル化剂や Rf基導入に使用するパーフルオロア ルキル化剂も報告されており，しばしば合成に利用されてい る.

\section{1. トリフルオロメチル基導入方法}

1）求核的トリフルオロメチル化剂（図 8)

いわゆる $\mathrm{CF}_{3}$ マイナスとして反応する試薬で ${ }^{\mathrm{a}-\mathrm{e} e)}$, 古くは $\mathrm{CF}_{3} \mathrm{I}$ と $\mathrm{Cu}$ にるウルマン型のカップリング反応が知られて いる ${ }^{9 a)}$. このタイプの反応はトリフルオロ酶酸やトリフル オロ酢酸エステル，フルオロスルホニルジフルオロ酢酸エ ステルの熱分解を経由しても進行し ${ }^{9 \mathrm{fg}, \mathrm{g}}$, また $\mathrm{CF}_{3} \mathrm{TMS}$ から $\mathrm{CF}_{3} \mathrm{Cu}$ 塩に導く方法も報告されている (式14-17 $)^{9 \mathrm{~h})}$. これ らの反応ではこれまで銅を当量以上使用する必要があった が, 最近網井らによって触媒量のCuIによるカップリング 反応の例も報告された (式 18$)^{{ }^{9 i}}$. 一方, $\mathrm{CF}_{3} \mathrm{TMS}$ は骨格上 の炭素-ケイ素結合をアルカリまたは $\mathrm{F}^{-}$で切断することで 効果的に $\mathrm{CF}_{3}$ アニオンが発生するため, アルデヒド, ケト ン, エステル類のカルボニル基に $\mathrm{CF}_{3}$ 基を求核付加させるこ

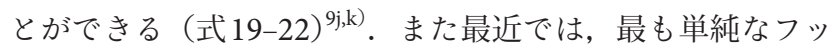
素化合物であるフロロホルム $\left(\mathrm{CF}_{3} \mathrm{H}\right)$ を使って $\mathrm{CF}_{3}$ 基を導 入する方法がGrushin らによって報告された ${ }^{91)}$.この方法 によると, $\mathrm{CF}_{3} \mathrm{H}$ を $\mathrm{CuCl}$ の存在下に $\mathrm{DMF}$ 溶媒中で2当量の $t$-BuOKで処理することによって $[\mathrm{K}(\mathrm{DMF})]\left[\mathrm{Cu}(\mathrm{OtBu})_{2}\right]$ 錯体を経由して $\mathrm{CF}_{3} \mathrm{Cu}$ を効果的に合成できる（式23）。その 後, Prakash や柴田らは強い塩基によって $\mathrm{CF}_{3} \mathrm{H}$ から直接プ ロトンの引き抜きを行い $\mathrm{CF}_{3}^{-}$を発生させることに成功して いる $(\text { 式 } 24,25)^{9 \mathrm{~m}, \mathrm{n})}$.

2）親電子的トリフルオロメチル化剂（図9）

$\mathrm{CF}_{3}$ プラス型の反応として $\mathrm{CF}_{3}$ 基を導入するのがいわゆ る親電子型トリフルオロメチル化剂である. 図8 亿示す Umemoto試薬 ${ }^{10 a}$ やTogni 試薬（1,3-ジヒドロ-3,3-ジメチ ル-1-(トリフルオロメチル)-1,2-ベンズヨードキソール) ${ }^{10 b)}$ がこの部類に属する。これら試薬は試薬会社から購入できる 非常に便利なフッ素化剂であり, 探索研究の段階でよく利用 されている.これら試薬を用いることでカルバニオンやエナ ミンを含む各種エノール誘導体, 芳香族化合物など電子豊富 な基質の $\mathrm{CF}_{3}$ 化が可能となる（式26,27）.

3）ラジカル的トリフルオロメチル化剂

もう一つの様式として $\mathrm{CF}_{3}$ ラジカル型の反応がある. $\mathrm{CF}_{3} \mathrm{I}$ 
CF3-I, CF3-SiMe,$\quad$, CF3-SiEt ${ }_{3}, \mathrm{CF}_{3} \mathrm{COOM}, \quad \mathrm{FSO}_{2} \mathrm{CF}_{2} \mathrm{COOMe}_{3} \mathrm{CF}_{3} \mathrm{H}$

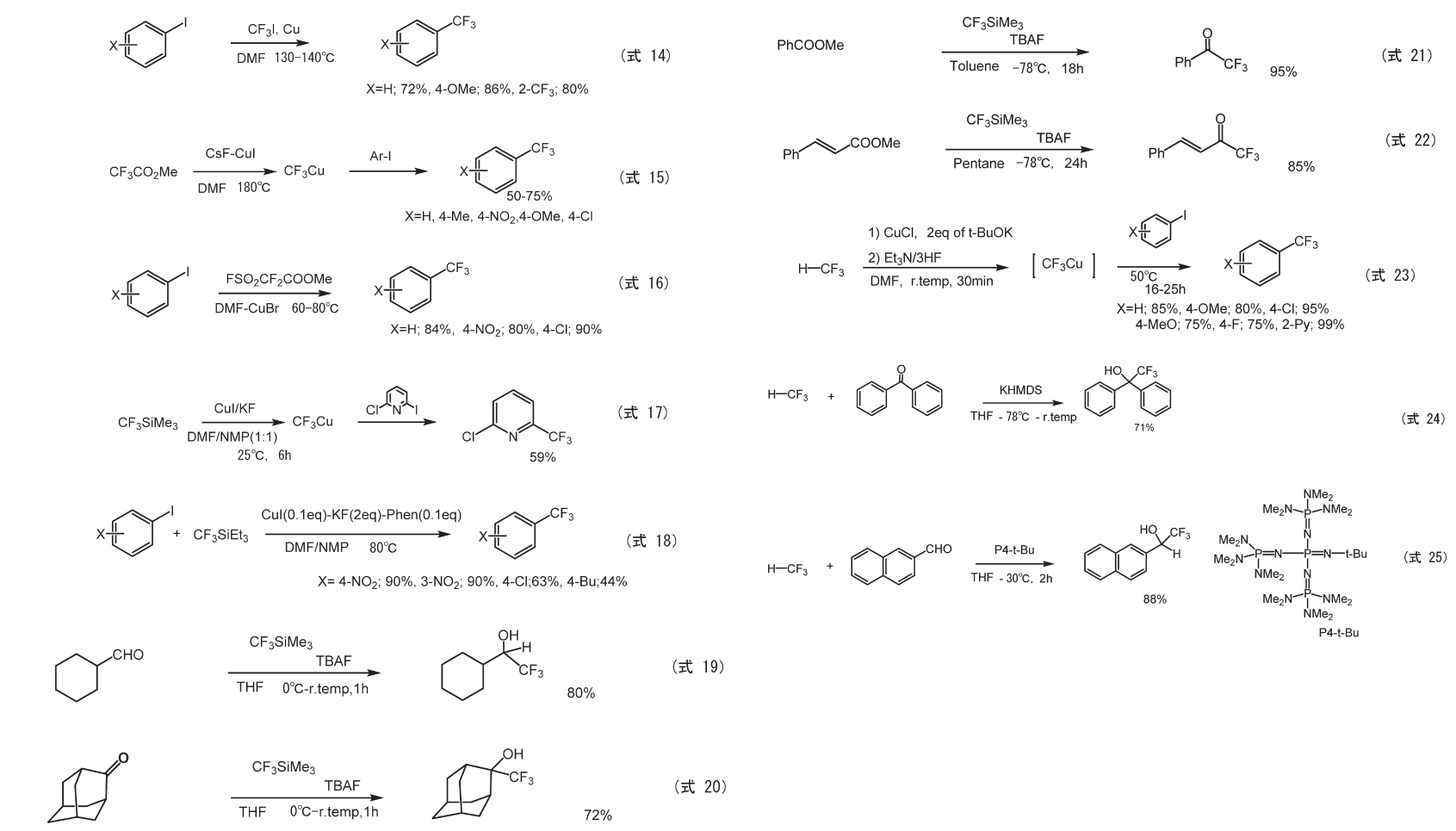

図8. 求核的トリフルオロメチル化剂.

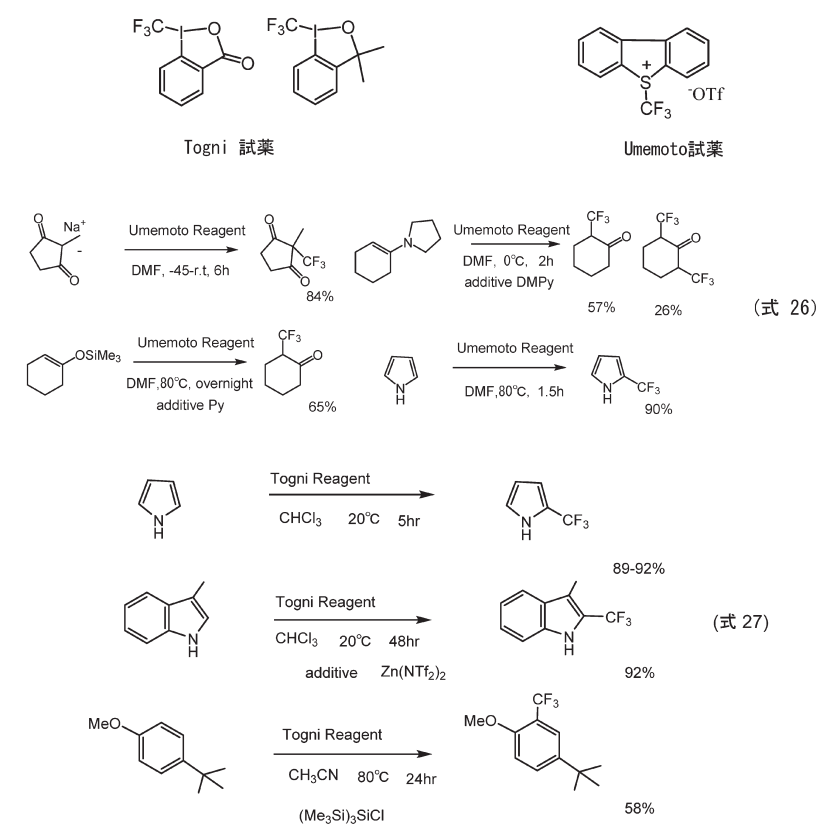

図9. 親電子的トリフルオロメチル化剂.

は前述したように $\mathrm{CF}_{3}$ マイナス化剂として有効な化合物であ るが，Fentoneラジカル型反応に供することによって各種へ テロ芳香族に対して効果的に $\mathrm{CF}_{3}$ 基を導大することができ る.またこの反応は $\beta$-ケトエステル等の各種活性メチレン 化合物への展開も可能である.この反応は $\mathrm{H}_{2} \mathrm{O}_{2}$ と 2 価の鉄

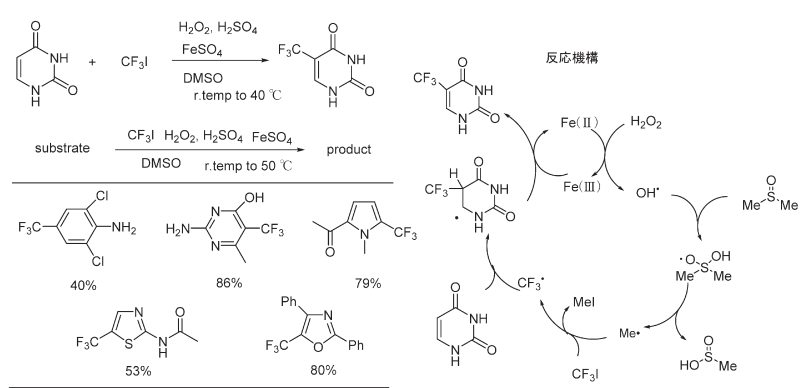

図 10. $\mathrm{CF}_{3} \mathrm{I}$ を用いるラジカル的 $\mathrm{CF}_{3}$ 化反応.

イオンから発生させたヒドロキシラジカルが DMSO から $\mathrm{Me}$ ラジカルを生成させ, この $\mathrm{Me}$ ラジカル経由で生成する $\mathrm{CF}_{3}$ ラジカルがウラシルに付加する反応機構が提案されている (図 10) ${ }^{11 a)}$. 同じくトリフルオロメチルスルフィン酸の $\mathrm{Na}$ 塩から発生させた $\mathrm{CF}_{3}$ ラジカルで $\mathrm{CF}_{3}$ 基を導入する方法も報 告されている. 反応させる基質は前述の例と同じで, 各種 ヘテロ芳香族に対して効率よく $\mathrm{CF}_{3}$ 化が進行する．この反応 では $t-\mathrm{BuO}$ ラジカルを介してスルフィニルイオンから脱 $\mathrm{SO}_{2}$ して $\mathrm{CF}_{3}$ ラジカルを発生させている(図 11) ${ }^{11 \mathrm{~b})}$. また, Ruppert-Prakash試薬を使ったラジカル反応の例も報告され ている. 銀のトリフラート存在下にKFで炭素-ケイ素結合 を切断し，いったん $\mathrm{CF}_{3} \mathrm{Ag}$ とした後これをラジカル源とす る方法である(図 12$)^{11 c)}$. 


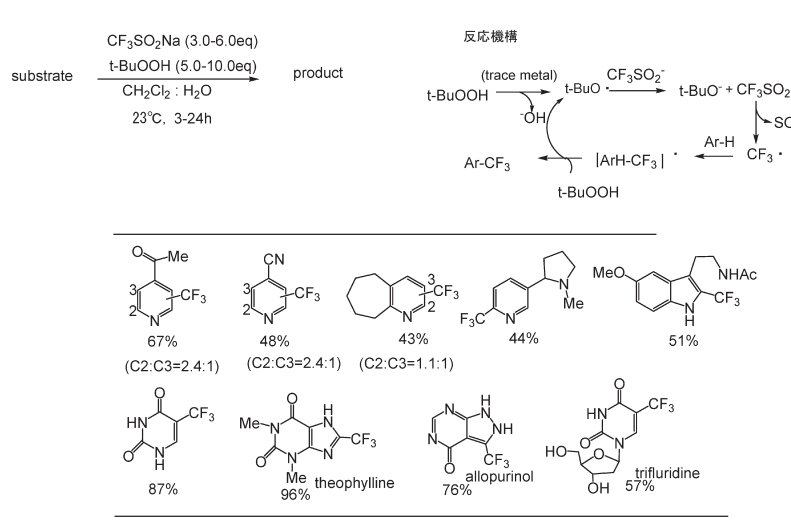

図 11. $\mathrm{CF}_{3} \mathrm{SO}_{2} \mathrm{Na}$ を用いるラジカル的 $\mathrm{CF}_{3}$ 化反応.

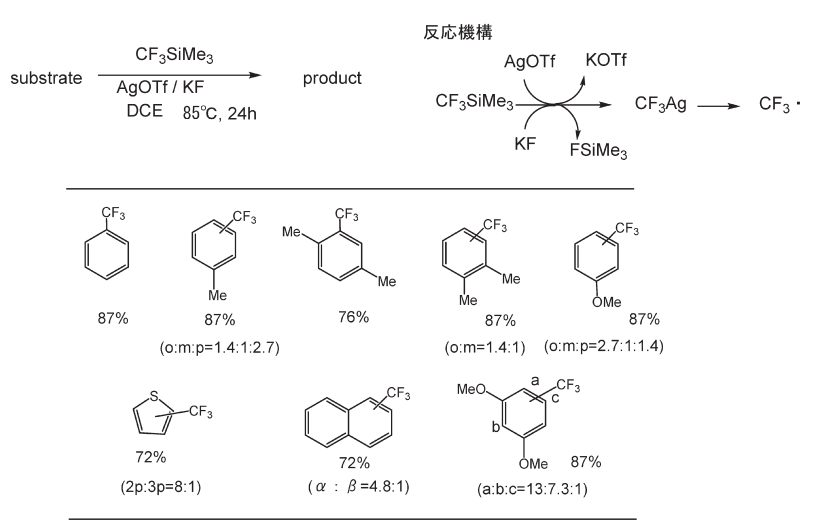

図 12. Ruppert-Prakash試薬を用いるラジカル的 $\mathrm{CF}_{3}$ 化反応.

\section{2. ジフルオロメチル基導入方法}

この方法に用いられる試薬には $\mathrm{CHF}_{2}-\mathrm{SiMe}_{3}$ がある。こ の試薬はRuppert-Prakash試薬をDiglyme溶媒中 $\mathrm{NaBH}_{4}$ で還元することによって合成されている(式28) ${ }^{12 a)}$ 。こ の $\mathrm{CHF}_{2}-\mathrm{SiMe}_{3}$ は炭素-ケイ素結合を開裂することによっ て Ruppert-Prakash試薬と同様に $\mathrm{CHF}_{2}^{-}$源として利用でき る. Hartwig らは $\mathrm{CHF}_{2}-\mathrm{SiMe}_{3}$ を用いて，芳香族ヨウ化物や ヨウ化ビニル化合物への $\mathrm{CHF}_{2}$ 基導入反応について報告し

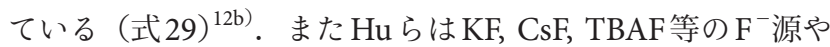
$t$ - $\mathrm{BuOK}$ を $\mathrm{CHF}_{2}-\mathrm{SiMe}_{3}$ に対して過剰量使用することによっ て温和な条件下でアルデヒドやケトン化合物に $\mathrm{CHF}_{2}$ 基を効 果的に導入する方法について述べている（式 30 $)^{12 c)}$. さら にRuppert-Prakash試薬から発生させた $\mathrm{CF}_{3}^{-}$からフッ素を $\alpha$ 脱離させて安定な $\mathrm{CF}_{2}$ カルベンに誘導した後, オレフィン類 にカルベン付加させることによるジフルオロシクロプロパン 骨格の合成にも成功している（式 31) ${ }^{12 \mathrm{~d})}$. Ruppert-Prakash 試薬経由でのジフルオロカルベン生成は $-50^{\circ} \mathrm{C}$ から室温と いう非常に穏和な条件下に進行するため，デリケートな基 質のシクロプロパン化に対しては非常に優れた手法である と言える。また彼らはRuppert-Prakash試薬とCuI とから生 成する $\mathrm{CF}_{3} \mathrm{Cu}$ をジアゾ化合物と反応させた後, $\mathrm{F}^{-}$を $\beta$ 脱離 させることによるジフルオロオレフィン類の合成について
$\mathrm{CF}_{3}-\mathrm{SiMe}_{3} \underset{\text { diglyme, r.temp }}{\stackrel{\mathrm{NaBH}_{4}}{\longrightarrow}} \quad \begin{array}{r}\mathrm{CHF}_{2}-\mathrm{SiMe}_{3} \\ 70 \%\end{array} \quad$ (式 28)
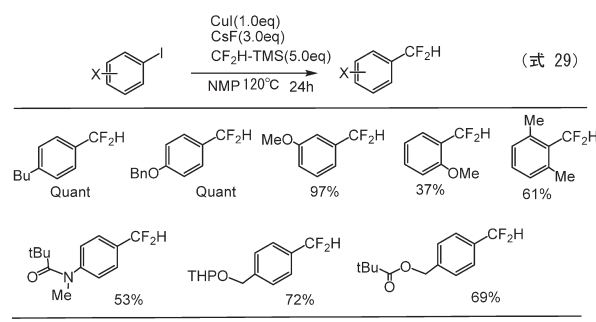

Difluoromeethylation of Aldehydes

$\mathrm{CHF}_{2}-\mathrm{SiMe}_{3}+\mathrm{R}$ $\mathrm{R}=\mathrm{p}-\mathrm{OMe} ; 91 \%$, o-Cl; $92 \%, \mathrm{~m}-\mathrm{Cl} ; 96 \%, 2,4-\mathrm{Cl}, \mathrm{Cl} ; 67 \%$,

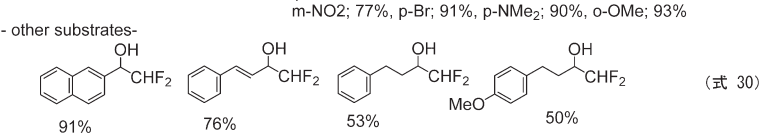

Difluoromeethylation of Ketones

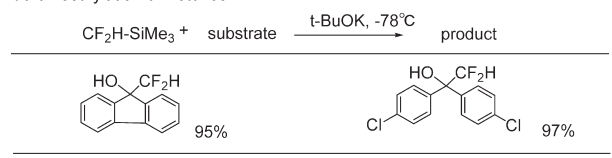
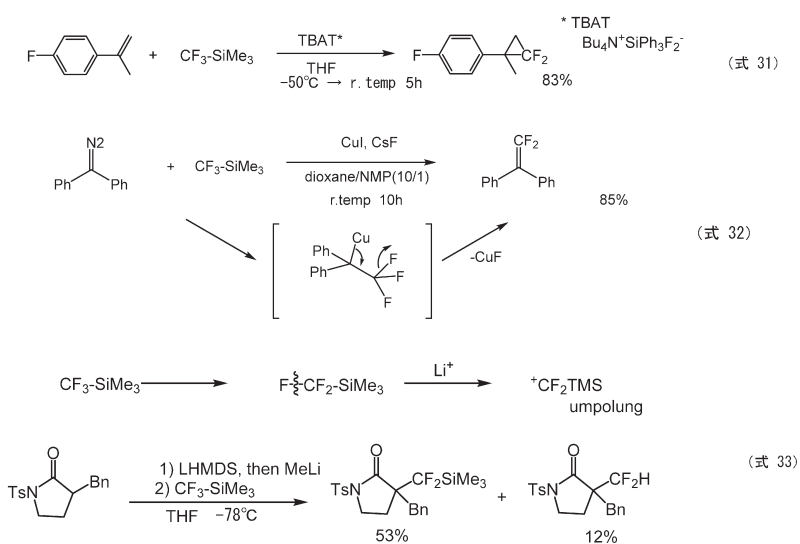

も報告している（式 32) ${ }^{12 \mathrm{e})}$ 。一方三上らのグループは，低 温でLiHMDSを使って発生させた Liエノラートが RuppertPrakash試薬のフッ素原子を $\mathrm{F}^{-}$として引き抜くことができる と報告した。さらにその結果生成する $\mathrm{CF}_{2} \mathrm{SiMe}_{3}$ カチオンを 親電子的に反応させることによって $\mathrm{CF}_{2} \mathrm{SiMe}_{3}$ 基を導入し， 次いでその $\mathrm{C}-\mathrm{Si}$ 結合を $\mathrm{F}^{-}$源で切断してやることでアルデヒ ドやカルボニル化合物への付加反応に成功した（式 33） ${ }^{12 f)}$.

\section{3. モノフルオロメチル基導入方法}

最近柴田らによって光学活性なモノフルオロメチル基導 入反応が報告された ${ }^{13}$ ). この反応に用いる試薬（柴田試薬： FBSM 試薬）は，ビスフェニルスルフォニルメタンをフッ素 ガスで処理することによって容易に得られる。この試薬は触 媒量のキラルなリガンドと $\mathrm{Pd}\left(\mathrm{C}_{3} \mathrm{H}_{5}\right) \mathrm{Cl}_{2}$ との錯体存在下に 各種䣷酸アリル誘導体と温和な条件下に反応して, 対応する 
フルオロビスフェニルスルホニルメチル体をエナンチオ選択 的に与える (式 34). こうして得られたフルオロビスフェニ ルスルホニルメチル体はメタノール中で活性な $\mathrm{Mg}$ と処理す ることによって容易にスルホニル基が脱離し，対応するモノ フルオロメチル化合物に変換できる.

\section{4. パーフルオロアルキル基導入方法}

芳香族化合物への Rf基導入方法としては主としてパー フルオロアルキルハライドがこの目的に使用されている. $\mathrm{CF}_{3} \mathrm{I}$ による $\mathrm{CF}_{3}$ 化反応と同様，パーフルオロアルキルハラ イドと Cuによるウルマン型カップリング反応が古くから利 用されてきたが (式 35) ${ }^{14 a)}$ ，最近ではRuppert-Prakash試薬 様化合物による求核型反応や (式 36$)^{14 b)}$, 還元的ラジカル カップリング反応 (式 37) ${ }^{14 c)}$, Fentone型ラジカルカップリ ング反応 $(\text { 式 } 38)^{14 \mathrm{~d})}$, 亜鉛アート錯体を用いてパーフルオ ロアルキルアニオンを経由する Rf基導入反応（式 39) ${ }^{14 \mathrm{e} ） な ~}$

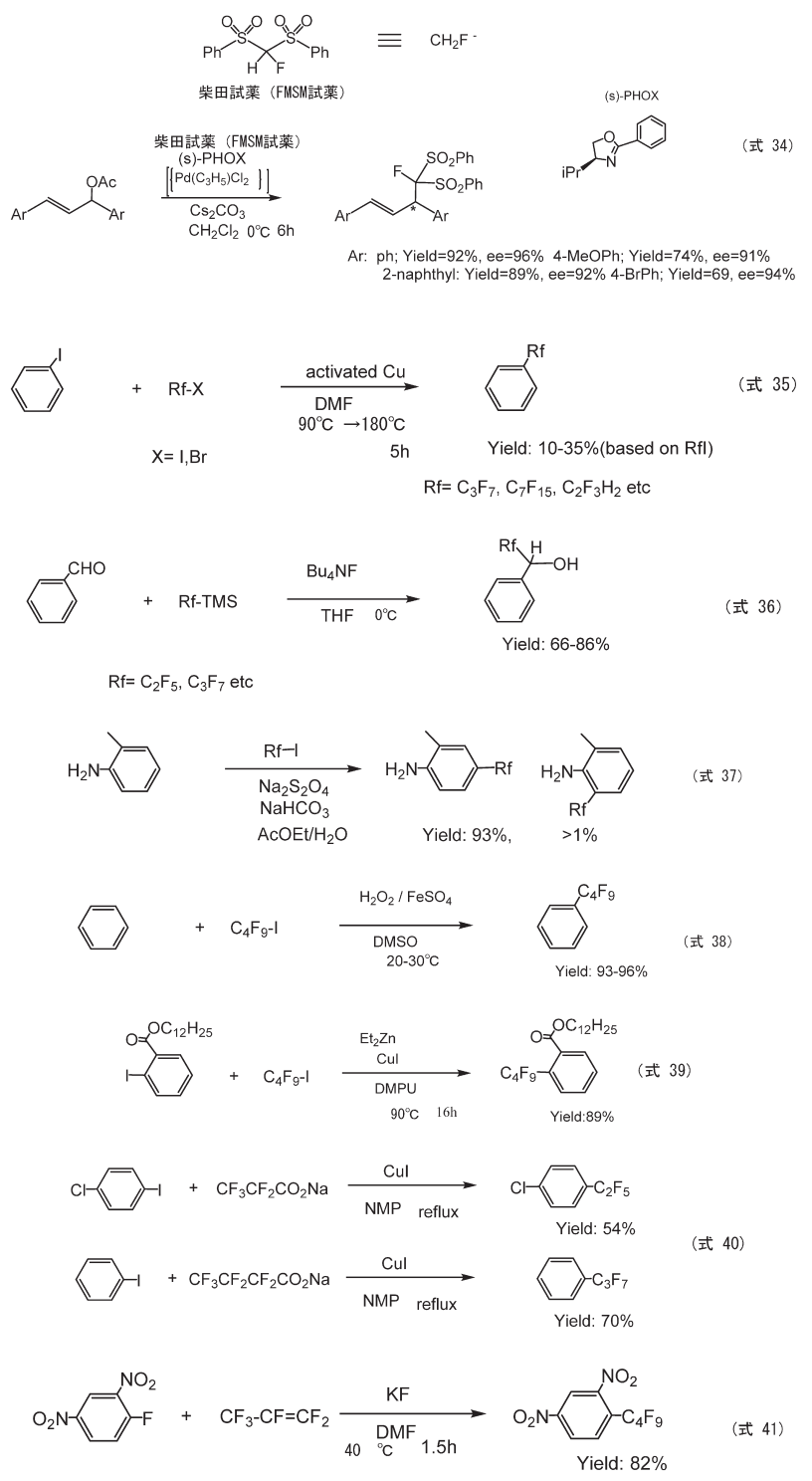

どが報告されている。そのほかにも，パーフルオロカルボ ン酸から脱炭酸反応を経由してRf化する反応や $(\text { 式 } 40)^{14 f)}$, パーフルオロアルケン類に求核的付加を行う反応もよく知ら れている $(\text { 式 } 41)^{14 \mathrm{~g})}$.

\section{3. 医・農薬への応用展開}

本章では，前述したフッ素官能基導入方法を実際の医農薬 開発に応用展開している例についていくつか紹介していく.

3.1. ボリコナゾール（図 13）

2002年にPfizerから上市された抗HIVウイルス感染症治 療薬である。おもにカリ二肺炎治療に使用される。フッ素 を含むピリミジン骨格は, 当初5-フルオロウラシルから段 階的に合成されていたが目的物までの収率が $45 \%$ と低いた め, 別途合成法として $\beta$-ケトエステルを $\mathrm{F}_{2}$ ガスで直接フッ 素化してフルオロケトエステルとし，これをアミジンで環 化してピリミジン骨格を合成する方法に改良されている（式 $42)^{15)}$.

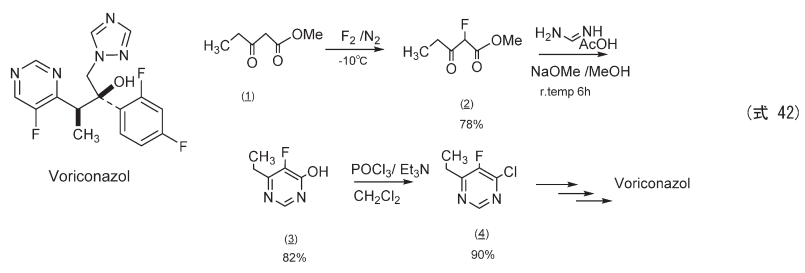

図13. ボリコナゾール

3.2. タフルプロスト（図 14）

旭硝子と参天製薬で開発された緑内障治療と眼圧治療用の プロスタグランジン製剤である。通常のCollyラクトンを出 発原料として $\alpha, \beta$-不飽和ケトンを合成後, このケトン部分 を求核的フッ素化剂であるMOSTでジフルオロ化してフッ 素原子を導入している $\left(\right.$ 式43） ${ }^{16)}$.

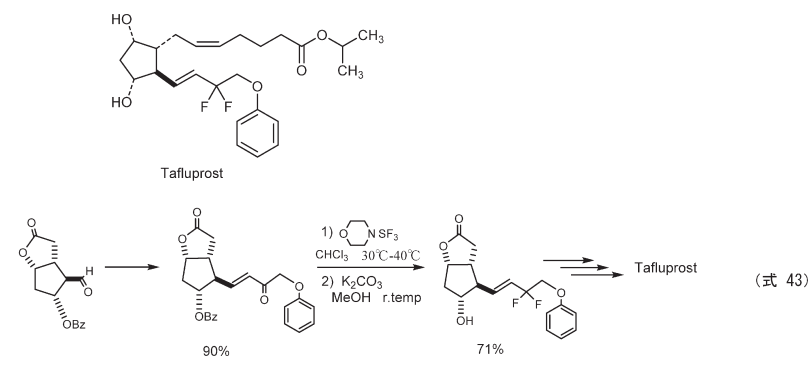

図14.タフルプロスト.

3.3. トリフルリジン（図 15）

核酸系の抗悪性腫瘍剂, 抗ウイルス剂である. 極最近チピ ラシル塩酸塩との配合剂が, 5-FU抵抗性の進行性, 再発大 腸癌の治療薬として大鵬薬品よりロンサーフ配合錠として上 市された，主要骨格であるトリフルオロチミンは，ウラシル 
を $\mathrm{CF}_{3} \mathrm{I}$ または $\mathrm{CF}_{3} \mathrm{SO}_{2} \mathrm{Na}$ より発生させた $\mathrm{CF}_{3}$ ラジカルで直 接 $\mathrm{CF}_{3}$ 化して合成されている（式44）
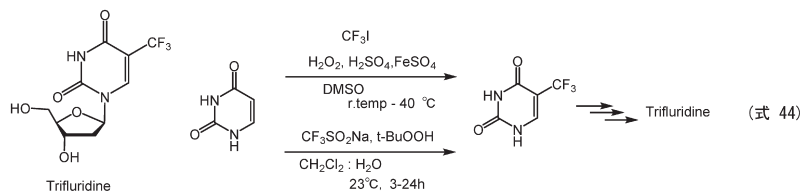

図15.トリフルリジン.

\section{4. フィプロニル（図 16）}

ローヌ・プーラン（現バイエルクロップサイエンス）が開 発したフェニルピラゾール系殺虫薬である。広範囲の害虫 や, 犬・猫等のノミ退治に用いられる。トリフルオロメチル チオピラゾール骨格は, 対応する二硫化ピラゾールをDMF 中でギ酸ナトリウムおよび $\mathrm{SO}_{2}$ 存在下に $\mathrm{CF}_{3} \mathrm{Br}$ と反応する方

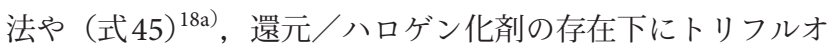
ロメタンスルフィン酸ナトリウムとピラゾールを反応させる 方法 (式 46$)^{18 b)}$ が工業的製法として示されている.

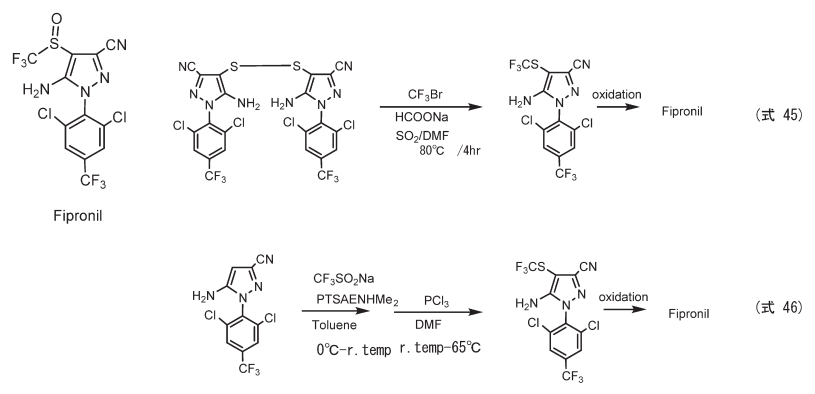

図16. フィプロニル.

\section{5. フルベンジアミド（図 17）}

2007 年に日本農薬から上市された殺虫剂である。この化合 物の基本骨格にはパーフルオロイソプロピル基を有するアニ リン誘導体がアミド結合している。このアニリン誘導体は, 反応開始剂として带ジチオン酸 $\mathrm{Na}$ の存在下にトルイジンと パーフルオロイソプロピルアイオダイドを反応させること によって1段階で非常に効率よくパラ選択的に合成されてい る ${ }^{19 a)}$. ちなみにパーフルオロイソプロピルアイオダイドは, ヘキサフルオロプロペンにインターハロゲン $\mathrm{IF}_{5}$ を付加させ ることによって容易に合成することができる $(\text { 式 } 47)^{19 b)}$.

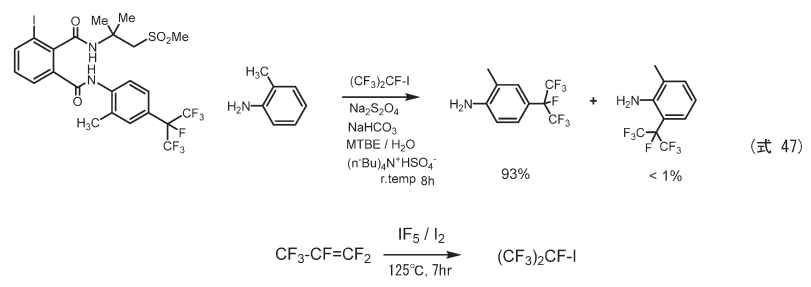

図17. フルベンジアミド.
3.6. ビクサフェン (図 18)

2006年にバイエルクロップサイエンスから上市された大 豆・トウモロコシなどに適用がある新規殺菌剤である。ジフ ルオロメチル基を有する含フッ素ピラゾール骨格とフルオロ ビフェニル骨格から構成されており，合成のポイントはピラ ゾール骨格の構築にある。 その後, シンジェンタやバスフか ら同様の含フッ素ピラゾール骨格を有する農薬類が相次いで 上市されている。この含フッ素ピラゾール骨格は, 最初対応 するジクロロ誘導体をジフルオロ化する最も一般的なハレッ クス法によって合成された（式 48$)^{20 a)}$. その後, ジフルオロ 䣷酸エステルを原料としてジフルオロケトエステルを経由す る閉環法や 20b,c) (式 49), 求核型フッ素化剂である TFEDMA 自身を出発原料にする方法が報告されている ${ }^{20 \mathrm{~d})}$ (式 50).

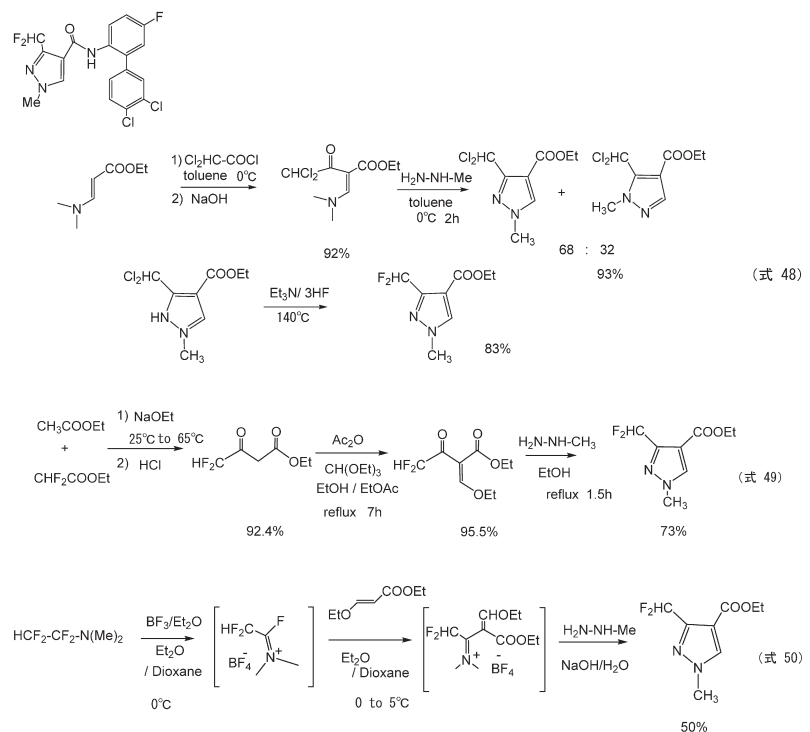

図18. ビクサフェン.

\section{4. おわりに}

含フッ素化合物の応用展開は, 医農薬の分野に限らずポリ マー材料や半導体・液晶分野などにも幅広く展開し, 我々の 生活と深くかかわっている。これら含〉ッ素化合物の多くは フルオロベンゼン等の比較的小分子の含フッ素誘導体を出発 原料とするビルディングブロック法によって基本骨格が構築 されてきたが, 最近ではユニークなフッ素官能基導入反応 や導入剂が数多く開発され，この反応を駆使してより複雑な 含フッ素骨格を効率よく合成する例も数多く見られるように なっている. 今回紹介したフッ素官能基導入方法はその一部 に過ざないが, 本分野での研究開発に携わる研究者の方々に 少しでも参考になれば幸いである. 


\section{引 用 文 献}

1) 日本学術振興会フッ素化学第 155 委員会編：フッ素化学入門 2010一基礎と応用の最前線, 三共出版, 2010.

2) M. Hauptschin and M. Braid: US3006973.

3a) N. N. Yarovenko and M. A. Raksha: J. Gen. Chem. USSR: Engl. Transl. 29, 2125-2128 (1959).

3b) A. Takaoka, H. Iwakiri and N. Ishikawa: Bull. Chem. Soc. Jpn. 52, 3377-3380 (1979).

3c) V. A. Petrov, S. Swearingen, W. Hong and W. Chris Petersen: J. Fluor. Chem. 109, 25-31 (2001).

4a) W. J. Middleton and E. M. Bingham: Org. Synth. 57, 50-52 (1977).

4b) S. Kuwahara, D. Itoh, W. S. Leal and O. Kodama: Tetrahedron Lett. 39, 1183-1184 (1998).

4c) G. S. Lal and G. P. Pez: US6080886.

4d) M. Hudlický: Org. React. 35, 513-641 (1988).

4e) A. L'Heureux, F. Beaulieu, C. Bennett, D. R. Bill, S. Clayton, F. La Flamme, M. Mirmehrabi, S. Tadayon, D. Tovell and M. Couturier: J. Org. Chem. 75, 34013411 (2010).

5a）園田 寛, 岡田一成, 高橋 章, 林 秀俊, 高野安広, 福村考 記，永田輝幸：特開2000-38370.

5b）園田＼cjkstart寛：ファインケミカル31 (10), 5-12 (2002).

5c) T. Umemoto and Y. Xu: WO2008013550.

5d) T. Umemoto and R. P. Singh: US7381846.

6a) L. V. Streng and A. G. Streng: Inorg. Chem. 4, 1370-1371 (1965).

6b) M. Zupan and A. Pollak: J. Org. Chem. 42, 1559-1562 (1977).

6c) S. P. Anand, L. A. Quaterman, H. H. Hyman, K. G. Migliorese and R. Filler: J. Org. Chem. 40, 807-809 (1975).

6d) C. A. Ramsden and M. M. Shaw: Tetrahedron Lett. 50, 33213324 (2009).

6e) S. Stavber and M. Zupan: J. Org. Chem. 50, 3609-3612 (1985).

6f) M. Zupan and A. Pollak: J. Org. Chem. 39, 2646-2647 (1974).

$6 \mathrm{~g})$ B. J. Magerlein, J. E. Pike, R. W. Jackson, G. E. Vandenberg and F. Kagan: J. Org. Chem. 29, 2982-2986 (1964).

7a) R. C. Kennedy and G. H. Cady: J. Fluorine Chem. 3, 41-54 (1973).

7b) M. J. Fifolt: US4499024.

7c) 大橋満也, 毛利 勇：特開2002-3451.

7d) S. Rozen and Y. Menahem: Tetrahedron Lett. 20, 725-728 (1979).

7e) O. Lerman, Y. Tor, D. Hebel and S. Rozen: J. Org. Chem. 49, 806-813 (1984).

7f) D. H. R. Barton, R. H. Hesse, G. P. Jackman, L. Ogunkoya and M. M. Pechet: J. Chem. Soc., Perkin Trans. 1, 739-742 (1974).

7g) M. J. Fifolt, R. T. Olczak, R. F. Mundhenke and J. F. Bieron: J. Org. Chem. 50, 4576-4582 (1985).

7h) O. Lerman, Y. Tor and S. Rozen: J. Org. Chem. 46, 4629-4631 (1981).

7i) S. Rozen and M. Brand: Synthesis 665-667 (1985).

8a) T. Umemoto and K. Tomita: Tetrahedron Lett. 27, 3271-3274 (1986).

8b) E. Differding and H. Ofner: Synlett 1991, 187-189 (1991).

8c) R. E. Banks, S. N. Mohialdin-Khaffaf, G. S. Lal, I. Sharif and R. G. Syvret: J. Chem. Soc. Chem. Commun., 595-596 (1992). 8d) T. Umemoto, M. Nagayoshi, K. Adachi and G. Tomizawa: J. Org. Chem. 63, 3379-3385 (1998).

9a) Y. Kobayashi and I. Kumadaki: Tetrahedron Lett. 10, 4095-4096 (1969).

9b) V. A. Petrov: Tetrahedron Lett. 42, 3267-3269 (2001).

9c) G. E. Carr, R. D. Chambers, T. F. Holmes and D. G. Parker: J. Chem. Soc. Perkin Trans. 1, 921-926 (1988).

9d) F.-L. Qing and J. Fan: J. Fluor. Chem. 96, 159-161 (1999).

9e) A. Zanardi, M. A. Novikov, E. Martin, J. Benet-Buchholz and V. V. Grushin: J. Am. Chem. Soc. 133, 20901-20913 (2011).

9f) B. R. Langlois and N. Roques: J. Fluor. Chem. 128, 1318-1325 (2007).

9g) Q. Chen and S. Wu: J. Chem. Soc., Chem. Commun., 705-706 (1989).

9h) F. Cottet and M. Schlosser: Eur. J. Org. Chem. 2002, 327-330 (2002).

9i) M. Oishi, H. Kondo and H. Amii: Chem. Commun. (Camb.), 1909-1911 (2009).

9j) G. K. S. Prakash, R. Krishnamurti and G. A. Olah: J. Am. Chem. Soc. 111, 393-395 (1989).

9k) G. K. S. Prakash and M. Mandal: J. Fluor. Chem. 112, 123131 (2001).

9l) A. Zanardi, M. A. Novikov, E. Martin, J. Bernet-Buchholz and V. V. Grushin: J. Am. Chem. Soc. 133, 20901-20913 (2011).

9m) G. K. S. Prakash, P. V. Jog, P. T. D. Batamack and G. A. Olah: Science 338, 1324-1327 (2012).

9n) H. Kawai, Z. Yuan, E. Tokunaga and N. Shibata: Org. Biomol. Chem. 11, 1446-1450 (2013).

10a) T. Umemoto and S. Ishihara: J. Am. Chem. Soc. 115, 2156-2164 (1993).

10b) P. Eisenberger, S. Gischig and A. Togni: Chemistry 12, 2579-2586 (2006).

11a) T. Kino, Y. Nagase, Y. Ohtsuka, K. Yamamoto, D. Uraguchi, K. Tokuhisa and T. Yamakawa: J. Fluor. Chem. 131, 98-105 (2010).

11b) Y. Ji, T. Bruecki, R. D. Baxter, Y. Fujiwara, I. B. Seiple, S. Su, D. G. Blackmond and P. S. Baran: Proc. Natl. Acad. Sci. U.S.A. 108, 14411-14415 (2011)

11c) Y. Ye, S. H. Lee and M. S. Sanford: Org. Lett. 13, 5464-5467 (2011).

12a) A. A. Tyutyunov, V. E. Boyko and S. M. Igoumnov: Fluorine Notes 78, 1-4 (2011).

12b) P. S. Fier and J. F. Hartwig: J. Am. Chem. Soc. 134, 5524-5527 (2012).

12c) Y. Zhao, W. Huang, J. Zheng and J. Hu: Org. Lett. 13, 5342-5345 (2011).

12d) F. Wang, T. Luo, J.-B. Hu, Y. Wang, H. S. Krishnan, P. V. Jog, S. K. Ganesh, G. K. S. Prakash and G. A. Olah: Angew. Chem. Int. Ed. 50, 7153-7157 (2011).

12e) M. Hu, Z. He, B. Gao, L. Li, C. Ni and J. Hu: J. Am. Chem. Soc. 135, 17302-17305 (2013).

12f) R. Hashimoto, T. Iida, K. Aikawa, S. Ito and K. Mikami: Chemistry 20, 2750-2754 (2014).

13) T. Fukuzumi, N. Shibata, M. Sugiura, H. Yasui, S. Nakamura and T. Toru: Angew. Chem. Int. Ed. 45, 4973-4977 (2006). 
14a) V. C. R. McLoughlin and T. J. Farnborough: US3408411.

14b) R. Krishnamurti, D. R. Bellew and G. K. S. Prakash: J. Org. Chem. 56, 984-989 (1991).

14c）大西正展, 好浦昭彦, 河野栄司, 津幡健治：特開2001-122836.

14d) A. Bravo, H.-R. Bjorsvik, F. Fontana, L. Liguori, A. Mele and F. Minisci: J. Org. Chem. 62, 7128-7136 (1997).

14e) 内山真伸, 平野圭一: 特開2015-086221.

14f) G. E. Carr, R. D. Chambers, T. F. Holmes and D. G. Parker: J. Chem. Soc. Perkin Trans. 1, 921-926 (1988).

14g）石川延男, 井上義雄: 有機合成協会誌 27, 993-997 (1969).

15) M. Butters, J. Ebbs, S. P. Green, J. MacRae, M. C. Morland, C. W. Murtiashaw and A. J. Pettman: Org. Process Res. Dev. 5, 28-36 (2001).

16) Y. Matsumura, N. Mori, T. Nakano, H. Sasakura, T. Matsugi, H. Hara and Y. Morizawa: Tetrahedron Lett. 45, 1527-1529 (2004).

17a) 山川 哲, 山本京子, 浦口大輔, 徳久賢治: 特開2007-153876.

17b) L. Luiu, D. Akalay, W. Dong, J. Feng, C. W. Hemp, J. Lu, L. Xie and J. Yang: US20140135497.

18a) U. Jensen-Korte, R. Gehring, O. Schallner, J. Stetter, H.-J. Wroblowsky, B. Becker, B. Homeyer, W. Behrenz, W. W. Stendel and P. Andrews: EP0201852. 18b) T.-K. Yang and E. Widmer: WO2009077853.

19a) 大西正展, 好浦昭彦, 河野栄司, 津幡健治：特開2001-122836.

19b) M. Hauptschein and M. Braid: US3006973.

20a) R. Lantzsch, W. Jorges, S. Pazenok and W. Joerges: US20060252944.

20b) V. Maywald, S. P. Smidt, B. Wolf, C. Koradin, T. Zierke, M. Rack and M. Keil: WO2009106619.

20c) M. J. Graneto and W. G. Phillips: US5093347.

20d) M. Nett, T. Grote, J. Lohmann, J. Dietz, S. P. Smidt, M. Rack and T. Zierke: US20100184994.

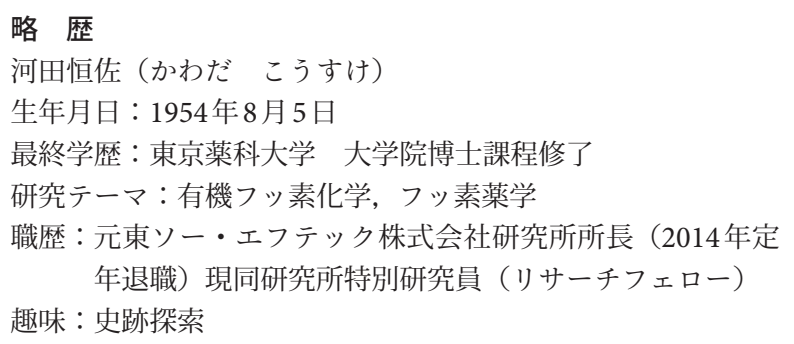

